\title{
ANALISIS PAJAK DAERAH DAN RETRIBUSI DAERAH DALAM STRUKTUR PENDAPATAN ASLI DAERAH KOTA MANADO
}

\author{
Ali Kurniawan A. Suratinoyo \\ Harijanto Sabijono \\ Stanly Alexander \\ Fakultas Ekonomi dan Bisnis, Jurusan Akuntansi \\ Universitas Sam Ratulangi Manado \\ email : ali_kurniawan78@yahoo.com
}

\begin{abstract}
ABSTRAK
Pendapatan Asli Daerah (PAD) merupakan penerimaan dari pungutan pajak daerah, retribusi daerah, pengelolaan kekayaan daerah yang dipisahkan dan pendapatan lain-lain. Semakin tinggi PAD dalam pendapatan daerah merupakan cermin keberhasilan tingkat kemampuan daerah dalam pembiayaan penyelenggaraan pemerintahan dan pembangunan. Pajak daerah dan Retribusi Daerah merupakan sumber Penerimaan utama bagi Pendapatan Asli Daerah yang digunakan untuk membiayai penyelenggaraan pemerintahan dan pembangunan. Tujuan dilaksanakannya penelitian ini untuk mengetahui pertumbuhan pajak daerah dan retribusi daerah dalam struktur pendapatan asli daerah (PAD) Kota Manado. Data yang diolah adalah data dari DISPENDA Kota Manado dari tahun 2007-2011. Metode analisis data yang digunakan adalah metode deskriptif yaitu menganalisis data realisasi pajak daerah dan retribusi daerah tahun 2007-2011 yang didapat dari Dinas Pendapatan Daerah Kota Manado. Hasil penelitian ini menunjukkan bahwa kontribusi yang diberikan pajak daerah dan retribusi daerah terhadap PAD dari tahun 2007-2011 yaitu sebesar 65,18\% untuk pajak daerah dan 23,16\% untuk retribusi daerah. Kurangnya jumlah penerimaan retribusi daerah jika dibandingkan dengan pajak daerah, maka sebaiknya pemerintah daerah Kota Manado lebih mengoptimalkan jasa layanan yang diberikan, baik yang sifatnya komersial maupun yang berbentuk layanan publik.
\end{abstract}

Kata kunci : pendapatan asli daerah, pajak daerah dan retribusi daerah

\begin{abstract}
Local Revenue constitutes acceptance of levy local taxes, retribution, separated management of regional assets and other income. The higher income of regional income was an image of success level ability in financing administering government and regional development. Local taxes and retribution is a major source of Acceptance for local revenue used to finance governance and development. Purpose of the implementation of this study to determine the growth of local taxes and retribution in the revenue structure of Manado. The processed data is the data from the Office of Manado City revenues from 2007 to 2011. Data analysis method used is descriptive method to analyze the data of actual local taxes and retribution years 2007-2011 were obtained from the Regional Revenue Office of Manado City. Results of this study indicate that the contribution of a given local taxes and retribution to revenue from 2007 to 2011 in the amount of $65.18 \%$ to $23.16 \%$ and local taxes for retribution. The lack of total revenues compared to retribution local taxes, the local government should further optimize Manado services rendered, whether commercial in nature or in the form of public service.
\end{abstract}

Keywords : local revenue, local taxes and retribution 


\section{PENDAHULUAN}

\section{Latar Belakang}

Sejak tanggal 1 januari 2001 era otonomi daerah secara resmi diberlakukan di Indonesia menghendaki daerah untuk berkreasi dalam mencari sumber penerimaan yang dapat membiayai pengeluaran pemerintah daerah dalam rangka menyelenggarakan pemerintahan dan pembangunan. Otonomi daerah yang diterapkan di Indonesia hingga saat ini merupakan wujud dari diberlakukannya desentralisasi. Otonomi merupakan hak, wewenang, dan kewajiban daerah otonom untuk mengatur dan mengurus sendiri urusan pemerintahan dan kepentingan masyarakat setempat sesuai dengan peraturan perundang-undangan. Hal ini selaras dengan diberlakukannya UU No.32 Tahun 2004 tentang Pemerintah Daerah. Kinerja dan kemampuan keuangan daerah merupakan salah satu ukuran yang dapat digunakan untuk melihat kemampuan daerah dalam menjalankan otonomi daerah. Potensi daerah baik berupa sumber daya alam (SDA) maupun sumber daya manusia (SDM) tidak tersebar secara merata pada tiap-tiap daerah otonom.

Pemberlakuan Undang-Undang Nomor 28 Tahun 2009 tentang Pajak Daerah dan Retribusi Daerah yang mulai diberlakukan sejak tanggal 1 Januari 2010 menandai reformasi perpajakan daerah dan retribusi daerah di Indonesia. Pajak daerah dan retribusi daerah yang adalah bagian dari pendapatan asli daerah diharapkan mampu menjadi salah satu sumber pembiayaan penyelenggaraan pemerintahan dan pembangunan daerah untuk meningkatkan kesejahteraan masyarakat.

Pemberlakuan pajak dan retribusi daerah sebagai sumber penerimaan daerah pada dasarnya tidak hanya menjadi urusan pemerintah daerah sebagai pihak yang menetapkan dan yang memungut pajak dan retribusi daerah, tetapi juga berkaitan dengan masyarakat pada umumnya. Upaya ke arah kemandirian daerah, memerlukan kemandirian sumber pendapatan asli daerah yang perlu ditingkatkan, terutama dalam mengantisipasi semakin terbatasnya kemampuan pemerintah pusat dalam penyedian dana bagi daerah.

Untuk itu maka pemerintah daerah diharapkan untuk mampu menggali segenap potensi yang dimiliki oleh daerah tersebut baik potensi dari sumber daya alam dan sumber daya manusia berdasarkan asas keadilan dan asas manfaat. Dapat dilihat bahwa keunggulan kota Manado berasal dari beberapa bidang yang berupa pariwisata, pertanian, perkebunan, pertanian, perdagangan, perhotelan, dan restoran serat didukung oleh sumber daya manusia yang cukup memadai untuk mencapai kemandirian keuangan daerah.

\section{Tujuan Penelitian}

Tujuan yang ingin dicapai dalam penelitian ini adalah untuk mengetahui dan menganalisis pertumbuhan pajak daerah dan retribusi daerah dalam struktur pendapatan asli daerah (PAD) Kota Manado.

\section{Konsep Akuntansi Pengertian Akuntansi}

Horngren, et al (2009: 4) yang menyatakan akuntansi adalah sistem informasi yang mengukur aktivitas bisnis, memproses informasi menjadi laporan keuangan, dan mengkomunikasikan hasilnya kepada para pembuat keputusan.

Weygandt, et al (2007 : 4) mendefinisikan akuntansi (accounting) adalah suatu sistem informasi yang mengidentifikasikan, mencatat, dan mengkomunikasikan peristiwa-peristiwa ekonomi dari suatu organisasi kepada para pengguna yang berkepentingan.

Akuntansi adalah sistem informasi yang menghasilkan laporan kepada pihak-pihak yang berkepentingan mengenai aktivitas ekonomi dan kondisi perusahaan (Agoes dan Trisnawati, 2010:2).

\section{Akuntansi Pemerintahan}

Bastian dalam Mursyidi (2009 : 1) mendefinisikan akuntansi sektor publik sebagai mekanisme teknik dan analisis akuntansi yang diterapkan pada pengelolaan dana masyarakat di lembaga-lembaga tinggi negara dan departemen-departemen dibawahnya, pemerintah daerah, BUMN, BUMD, LSM dan yayasan sosial, maupun pada proyek-proyek kerja sama sektor publik dan swasta. Akuntansi keuangan daerah adalah proses pengidentifikasian, pengukuran, pencatatan, dan pelaporan transaksi ekonomi (keuangan) dari entitas pemerintah daerah (kabupaten, kota, atau provinsi) yang dijadikan sebagai informasi dalam rangka pengambilan keputusan ekonomi yang diperlukan oleh pihak-pihak eksternal entitas pemerintah daerah (Halim, 2007 : 75). 


\section{Konsep Pajak \\ Pengertian Pajak}

Banyak definisi pajak yang dikemukakan oleh para ahli. Ilyas dan Burton (2011:6) mengemukakan beberapa pendapat pakar tentang definisi pajak diantaranya adalah sebagai berikut.

1. Soemitro, "Pajak adalah iuran rakyat kepada kas negara berdasarkan Undang-Undang (yang dapat dipaksakan) dengan tiada mendapat jasa-timbal (kontraprestasi), yang langsung dapat ditunjukan dan yang digunakan untuk membayar pengeluaran umum."

2. Soemahamidjaja, "Pajak adalah iuran wajib berupa uang atau barang, yang dipungut oleh penguasa berdasarkan norma-norma hukum, guna menutup biaya produksi barang-barang dan jasa-jasa kolektif dalam mencapai kesejahteraan umum."

3. Smeet, "Pajak adalah prestasi kepada pemerintah yang terutang melalui norma-norma umum, dan yang dapat dipaksakannya, tanpa adanya kontra-prestasi yang dapat ditunjukan dalam hal yang individual; maksudnya adalah untuk membiayai pengeluaran pemerintah."

\section{Fungsi Pajak}

Mardiasmo (2011:1) menyatakan bahwa fungsi pajak terbagi atas dua fungsi yaitu sebagai berikut.

1. Fungsi Anggaran (Budgetair)

2. Fungsi Mengatur (Regulered)

\section{Sistem Pemungutan Pajak}

Mardiasmo (2011:7-8) menyatakan bahwa tiga macam sistem pemungutan pajak yaitu sebagai berikut.

1. Official Assessment System

2. Self Assessment System

3. Witholding System

\section{Hambatan Pemungutan Pajak}

Mardiasmo (2011:8-9) menyatakan bahwa hambatan terhadap pemungutan pajak dapat dikelompokkan menjadi berikut ini.

1. Perlawanan pasif dimana masyarakat enggan (pasif) membayar pajak.

2. Perlawanan aktif meliputi semua usaha dan perbuatan yang secara langsung ditujukan kepada fiskus dengan tujuan untuk menghindari pajak.

\section{Asas Pemungutan Pajak}

Mardiasmo (2011:7) menyatakan bahwa asas pemungutan pajak antara lain sebagai berikut ini.

1. Asas Domisili (asas tempat tinggal)

2. Asas Sumber

3. Asas Kebangsaan

\section{Syarat Pemunggutan Pajak}

Mardiasmo (2011:2) menyatakan bahwa syarat pemungutan pajak adalah sebagai berikut.

1. Pemungutan pajak harus adil (Syarat Keadilan)

2. Pemungutan pajak harus berdasarkan undang-undang (Syarat Yurids)

3. Tidak mengganggu perekonomian (Syarat Ekonomis)

4. Pemungutan pajak harus efisien (Syarat Finansiil)

5. Sistem pemungutan pajak harus sederhana

\section{Teori-Teori yang Mendukung Pemungutan Pajak}

Terdapat beberapa teori yang menjelaskan atau memberikan justifikasi pemberian hak kepada negara untuk memungut pajak. Mardiasmo (2011:3) menyatakan bahwa teori-teori tersebut antara lain sebagai berikut.

1. Teori Asuransi

2. Teori Kepentingan

3. Pajak Daya Pikul

4. Teori Bakti

5. Teori Asas Daya Beli 


\section{Pengelompokan Pajak}

Mardiasmo (2011:5) menyatakan bahwa pengelompokan pajak terdiri atas tiga yaitu sebagai berikut.

1. Menurut golongannya

a. Pajak langsung, yaitu pajak yang harus dipikul sendiri oleh wajib pajak dan tidak dapat dibebankan atau dilimpahkan kepada orang lain.

b. Pajak tidak langsung, yaitu pajak yang pada akhirnya dapat dibebankan atau dilimpahkan kepada orang lain.

2. Menurut sifatnya

a. Pajak Subjektif, yaitu pajak yang berpangkal atau berdasarkan pada subjeknya, dalam arti memperhatikan keadaan dari wajb pajak.

b. Pajak Objektif, yaitu pajak yang berpangkal pada objeknya, tanpa memperhatikan keadaan diri wajb pajak.

3. Menurut lembaga pemungutan

a. Pajak pusat, yaitu pajak yang dipungut oleh pemerintah pusat dan digunakan untuk membiayai rumah tangga negara.

b. Pajak daerah, yaitu pajak yang dipungut oleh pemerintah daerah dan digunakan untuk membiayai rumah tangga daerah.

\section{Tarif Pajak}

Mardiasmo (2011:9) menyatakan bahwa ada empat tarif pajak yaitu sebagai berikut.

1. Tarif sebanding/proporsional

2. Tarif tetap

3. Tarif progresif

4. Tarif degresif

\section{Pajak Daerah}

Siahaan (2010:9) menyatakan bahwa pajak daerah merupakan pajak yang ditetapkan oleh pemerintah daerah dengan Peraturan Daerah (Perda), yang wewenang pemungutannya dilaksanakan oleh pemerintah daerah dan hasilnya digunakan untuk membiayai pengeluaran pemerintah daerah dalam melaksanakan penyelenggaraan pemerintahan dan pembangunan di daerah.

Pajak Daerah diatur dalam Undang-Undang Republik Indonesia No. 28 tahun 2009. Adapun pembagian pajak daerah Kabupaten/Kota terdiri dari berikut ini.

1. Pajak Hotel adalah pajak atas pelayanan yang disediakan oleh hotel. Hotel adalah fasilitas penyedia jasa penginapan/peristirahatan termasuk jasa terkait lainnya dengan dipungut bayaran, yang mencakup juga motel, losmen, gubuk pariwisata, wisma pariwisata, pesanggrahan, rumah penginapan dan sejenisnya, serta rumah kos dengan jumlah kamar lebih dari 10 (sepuluh).

2. Pajak Restoran adalah pajak atas pelayanan yang disediakan oleh restoran.

Restoran adalah fasilitas penyedia makanan dan/atau minuman dengan dipungut bayaran, yang mencakup juga rumah makan, kafetaria, kantin, warung, bar, dansejenisnya termasuk jasa boga/katering.

3. Pajak Hiburan adalah pajak atas penyelenggaraan hiburan.

Hiburan adalah semua jenis tontonan, pertunjukan, permainan, dan/atau keramaian yang dinikmati dengan dipungut bayaran.

4. Pajak Reklame adalah pajak atas penyelenggaraan reklame.

Reklame adalah benda, alat, perbuatan, atau media yang bentuk dan corak ragamnya dirancang untuk tujuan komersial memperkenalkan, menganjurkan, mempromosikan, atau untuk menarik perhatian umum terhadap barang, jasa, orang, atau badan, yang dapat dilihat, dibaca, didengar, dirasakan, dan/atau dinikmati oleh umum.

5. Pajak Penerangan Jalan adalah pajak atas penggunaan tenaga listrik, baik yang dihasilkan sendiri maupun diperoleh dari sumber lain.

6. Pajak Mineral Bukan Logam dan Batuan adalah pajak atas kegiatan pengambilan mineral bukan logam dan batuan, baik dari sumber alam di dalam dan/atau permukaan bumi untuk dimanfaatkan.

Mineral Bukan Logam dan Batuan adalah mineral bukan logam dan batuan sebagaimana dimaksud di dalam peraturan perundang-undangan di bidang mineral dan batubara. 
7. Pajak Parkir adalah pajak atas penyelenggaraan tempat parkir di luar badan jalan, baik yang disediakan berkaitan dengan pokok usaha maupun yang disediakan sebagai suatu usaha, termasuk penyediaan tempat penitipan kendaraan bermotor.

8. Pajak Air Tanah adalah pajak atas pengambilan dan/atau pemanfaatan air tanah. Air Tanah adalah air yang terdapat dalam lapisan tanahatau batuan di bawah permukaan tanah.

9. Pajak Sarang Burung Walet adalah pajak atas kegiatan pengambilan dan/atau pengusahaan sarang burung walet.

Burung Walet adalah satwa yang termasuk marga collocalia, yaitu collocalia fuchliap haga, collocalia maxina,collocalia esculanta, dan collocalia linchi.

10. Pajak Bumi dan Bangunan Perdesaan dan Perkotaan adalah pajak atas bumi dan/atau bangunan yang dimiliki, dikuasai, dan/atau dimanfaatkan oleh orang pribadi atau Badan, kecuali kawasan yang digunakan untuk kegiatan usaha perkebunan, perhutanan, dan pertambangan.

Bumi adalah permukaan bumi yang meliputi tanah dan perairan pedalaman serta laut wilayah kabupaten/kota.

Bangunan adalah konstruksi teknik yang ditanam atau dilekatkan secara tetap pada tanah dan/atau perairan pedalaman dan/atau laut.

11. Bea Perolehan Hak atas Tanah dan Bangunan adalah pajak atas perolehan hak atas tanah dan/atau bangunan.

Perolehan Hak atas Tanah dan/atau Bangunan adalah perbuatan atau peristiwa hukum yang mengakibatkandiperolehnya hak atas tanah dan/atau bangunan oleh orang pribadi atau Badan.

Hak atas Tanah dan/atau Bangunan adalah hak atas tanah, termasuk hak pengelolaan, beserta bangunan diatasnya, sebagaimana dimaksud dalam undang-undang di bidang pertanahan dan bangunan.

\section{Pengertian Retribusi}

Retribusi menurut Siahaan (2010:5) adalah pembayaran wajib dari penduduk kepada Negara karena adnya jasa tertentu yang diberikan oleh Negara bagi penduduknya secara perorangan. Menurut Pasal 1 ayat UU No. 28 Tahun 2009 pengertian retribusi daerah yaitu retribusi adalah pungutan daerah sebagai pembayaran atas jasa atau pemberian izin tertentu yang khusus disediakan dan/atau diberikan oleh pemerintah daerah untuk kepentingan orang pribadi atau badan.

\section{Ciri-Ciri Retribusi Daerah}

Beberapa ciri yang melekat pada retribusi daerah yang saat ini dipungut di Indonesia menurut siahaan (2010:6-7) adalah sebagai berikut.

1. Retribusi merupakan pungutan yang dipungut berdasarkan undang-undang dan peraturan daerah yang berkenaan.

2. Hasil penerimaan retribusi masuk ke kas pemerintah daerah.

3. Pihak yang membayar retribusi mendapatkan kontra prestasi (balas Jasa) secara langsung dari pemerintah daerah atas pembayaran yang dilakukannya.

4. Retribusi terutang apabila ada jasa yang diselenggarakan oleh pemerintah daerah yang dinikmati oleh orang atau badan.

5. Sanksi yang dikenakan pada retribusi adalah sanksi secara ekonomis, yaitu jika tidak membayar retribusi, tidak akan memperoleh jasa yang diselenggarakan oleh pemerintah daerah.

\section{Penggolongan Retribusi Daerah}

1. Retribusi Jasa Umum, Obyeknya adalah pelayanan yang disediakan oleh Pemerintah daerah untuk tujuan kepentingan dan kemanfaatan umum serta dapat dinikmati oleh orang pribadi atau badan. Sedangkan subjeknya adalah orang pribadi atau badan yang menggunakan /menikmati pelayanan jasa umum yang bersangkutan.

Jenis-jenis retribusi jasa umum adalah retribusi.

a. Pelayanan kesehatan

b. Pelayanan persampahan/ kebersihan

c. Penggatian biaya cetak Kartu Tanda Penduduk dan Akte Catatan Sipil

d. Pelayanan pemakaman dan pengabuan mayat

e. Pelayanan parkir di tepi jalan umum

f. Pelayanan pasar 
g. Pengujian kendaraan bermotor

h. Pemeriksaan alat pemadam kebakaran

i. Penggantian biaya cetak peta

j. Penyediaan dan atau penyedotan kakus

k. Pengolahan limbah cair

1. Pelayanan tera/tera ulang

m. Pelayanan pendidikan

n. Pengendalian menara telekomunikasi.

2. Retribusi Jasa Usaha, obyeknya adalah pelayanan yang diberikan oleh Pemerintah Daerah dengan menganut prinsip komersial, sedangkan subjeknya adalah orang pribadi atau badan yang menikmati/menggunakan jasa usaha yang bersangkutan. Jenis - jenis retribusi jasa usaha adalah retribusi.

a. Pemakaian kekayaan daerah

b. Pasar grosir dan pertokoan

c. Tempat pelelangan

d. Terminal

e. Tempat khusus parker

f. Tempar penginapan / pesanggrahan / villa

g. Rumah potong hewan

h. Pelayanan pelabuhan kapal

i. Tempat rekreasi dan olah raga

j. Penyeberangan di atas air

k. Penjualan produksi usaha daerah

3. Retribusi Perizinan Tertentu, obyeknya adalah kegiatan tertentu Pemerintah daerah dalam rangka pemberian izin kepada orang pribadi atau badan yang dimaksudkan untuk pembinaan, pengaturan, pengendalian dan pengawsan atas kegiatan pemanfaatan ruang, penggunaan sumber daya alam, barang prasarana, atau fasilitas tertentu guna melindungi kepentingan umum dan menjaga kelestarian lingkungan. Sedangkan subjeknya adalah orang pribadi atau badan yang memperoleh izin tertentu dari pemerintah daerah.

Jenis - jenis retribusi perizinan tertentu adalah retribusi.

a. Izin mendirikan bangunan

b. Izin Tempat penjualan minuman beralkohol

c. Izin gangguan

d. Izin trayek, dan

e. Izin usaha perikanan.

\section{Pendapatan Asli daerah}

Pendapatan asli daerah adalah penerimaan daerah dari berbagai usaha pemerintah daerah untuk mengumpulkan dana guna keperluan daerah yang bersangkutan dalam membiayai kegiatan rutin maupun pembangunannya, yang terdiri atas pajak daerah, retribusi daerah, bagian laba usaha milik daerah, dan lain-lain penerimaan asli daerah yang sah. Pasal 6 Undang-undang No. 32 tahun 2004 menyatakan pendapatan asli daerah berasal dari berikut ini yaitu sebagai berikut.

1. Hasil pajak daerah

2. Hasil retribusi daerah

3. Hasil perusahaan milik daerah dan hasil pengelolaan kekayaan daerah yang dipisahkan

4. Penerimaan dari dinas dan lain-lain pendapatan daerah yang sah. 
Tabel 1 Penelitian Terdahulu

\begin{tabular}{|c|c|c|c|c|c|c|}
\hline $\mathbf{N}$ & $\begin{array}{c}\text { Nama } \\
\text { Peneliti / } \\
\text { Tahun }\end{array}$ & Judul & $\begin{array}{l}\text { Motode } \\
\text { Analisis }\end{array}$ & Hasil Penelitian & Persamaan & Perbedaan \\
\hline 1 & $\begin{array}{l}\text { Amri } \\
\text { Siregar } \\
(2009)\end{array}$ & $\begin{array}{l}\text { Analisis Tingkat } \\
\text { Efektivitas Pajak } \\
\text { dan Retribusi Daerah } \\
\text { Sebagai Pendapatan } \\
\text { Asli Daerah (PAD) } \\
\text { Sumatera Utara }\end{array}$ & Deskriptif & $\begin{array}{l}\text { Hasil penelitian menunjukkan } \\
\text { bahwa tingkat efektivitas } \\
\text { penerimaan pajak dari tahun } \\
2003-2007 \text { adalah tinggi yaitu } \\
\text { berada di atas } 100 \% \text { sedangkan } \\
\text { kontribusi penerimaan pajak dan } \\
\text { retribusi daerah dari tahun 2003- } \\
2007 \text { terus menunjukkan angka } \\
\text { penurunan yang berarti. }\end{array}$ & $\begin{array}{l}\text { Peneliti } \\
\text { melakukan } \\
\text { penelitian pada } \\
\text { jenis pajak dan } \\
\text { retribusi } \\
\text { daerah }\end{array}$ & $\begin{array}{l}\text { Peneliti } \\
\text { menganalisis } \\
\text { beberapa variabel - } \\
\text { variabel seperti } \\
\text { Pendapatan } \\
\text { Domestik Regional } \\
\text { Bruto (PDRB) dan } \\
\text { Penanaman Modal } \\
\text { Dalam Negeri } \\
\text { (PMDN). }\end{array}$ \\
\hline 2 & $\begin{array}{l}\text { Septian Dwi } \\
\text { Kurniawan } \\
(2010)\end{array}$ & $\begin{array}{l}\text { Pengaruh } \\
\text { Penerimaan Pajak } \\
\text { Dan Retribusi } \\
\text { Daerah Terhadap } \\
\text { Peningkatan } \\
\text { Pendapatan Asli } \\
\text { Daerah Di } \\
\text { Kabupaten Ponorogo }\end{array}$ & Kuantitatif & $\begin{array}{l}\text { Hasil penelitian menunjukan } \\
\text { bahwa pajak daerah berpengaruh } \\
\text { positif terhadap pertumbuhan } \\
\text { ekonomi sebesar } 1,90 \text { dan } \\
\text { retribusi daerah berpengaruh } \\
\text { positif terhadap pertumbuhan } \\
\text { ekonomi sebesar } 0,873 \text {. }\end{array}$ & $\begin{array}{l}\text { Peneliti } \\
\text { melakukan } \\
\text { penelitian pada } \\
\text { jenis pajak dan } \\
\text { retribusi } \\
\text { daerah }\end{array}$ & $\begin{array}{l}\text { Peneliti } \\
\text { menganalisis } \\
\text { prosedur } \\
\text { pemungutan pada } \\
\text { objek yang berbeda }\end{array}$ \\
\hline
\end{tabular}

\section{Jenis Penelitian}

\section{METODE PENELITIAN}

Jenis penelitian yang digunakan adalah penelitian deskriptif dimana peneliti secara langsung mendatangi objek penelitian yaitu, Dinas Pendapatan Asli Dearah Kota Manado untuk memperoleh data-data dan informasi yang dibutuhkan.

\section{Prosedur Penelitian}

Prosedur penelitian yang digunakan dalam penelitian ini adalah sebagai berikut.

1. Observasi langsung ke objek penelitian guna untuk mengetahui perkembangan pertumbuhan pajak daerah dan retribusi daerah dalam struktur Pendapatan Asli Daerah Kota Manado.

2. Mengidentifikasi pajak daerah dan retribusi daerah.

3. Mengumpulkan literatur-literatur yang berhubungan dengan penelitian untuk dijadikan sebagai dasar acuan dalam menganalisa permasalahan yang ada.

4. Mempelajari data yang diterima dari Dinas Pendapatan Daerah Kota Manado

5. Mengolah data yang diterima dari Dinas Pendapatan daerah Kota Manado

6. Membandingkan hasil yang diperolah dengan teori yang ada.

7. Penarikan kesimpulan dari hasil penelitian dan memberikan saran-saran yang dianggap perlu.

\section{Metode Pengumpulan Data}

Salah satu kegiatan dalam penelitian ini adalah merumuskan teknik pengumpulan data sesuai dengan masalah yang diteliti. Agar diperoleh data dan keterangan yang lengkap maka harus menggunakan teknik pengumpulan data yang tepat. Untuk itu teknik yang digunakan dalam penelitian ini adalah studi lapangan, dimana dilakukan melalui studi lapangan terhadap Dinas Pendapatan Daerah yang merupakan objek penelitian, untuk mendapatkan data yang diperlukan serta peninjauan langsung ke lokasi penelitian. 


\section{Jenis Data}

Data yang digunakan dalam penelitian ini sebagian besar menggunakan data kuantitatif berupa Daftar Rincian Penerimaan Pendapatan Daerah Kota Manado (2007-2011). Di sisi lain, data kualitatif berupa struktur organisasi, tugas, visi, misi, tujuan, saran dan kepegaiwaian dari Dinas Pendapatan Daerah Kota Manado.

\section{Sumber Data}

Sumber data yang digunakan dalam penelitian ini yaitu data sekunder, berupa target dan realisasi penerimaan Pendapatan Asli Daerah mulai tahun 2007-2011 yang dapat diperoleh pada Dinas Pendapatan Daerah Kota Manado.

\section{Metode Analisis}

Analisis yang digunakan dalam penelitian ini adalah metode analisis deskriptif. Metode deskriptif adalah suatu analisis yang mengumpulkan, menyusun, mengolah, dan menganalisis data angka, agar dapat memberikan gambaran mengenai suatu keadaan tertentu sehingga dapat ditarik kesimpulan. Perhitungan angka-angka menggunakan rumus Analisis kontribusi.

\section{Definisi Operasional}

Dalam penelitian ini menggunakan beberapa variabel yang terkait, antara lain sebagai berikut.

1. Pajak daerah adalah iuran wajib yang dibayarkan oleh orang pribadi atau badan kepada daerah tanpa imbalan langsung yang seimbang, yang dapat dipaksakan berdasarkan peraturan perundang-undangan yang berlaku yang dikenakan untuk membiayai penyelenggaraan pemerintahan dan pembangunan daerah.

2. Retribusi adalah pungutan daerah sebagai pembayaran atas jasa atau pemberian ijin tertentu yang khusus disediakan oleh pemerintah daerah dengan menganut prinsip komersial karena pada dasarnya dapat pula disediakan oleh sektor swasta.

3. Pendapatan Asli Daerah adalah penerimaan daerah dari berbagai usaha pemerintah daerah untuk mengumpulkan dana guna keperluan daerah yang bersangkutan dalam membiayai kegiatan rutin maupun pembangunannya, yang terdiri atas pajak daerah, retribusi daerah, bagian laba usaha milik daerah, dan lainlain penerimaan asli daerah yang sah.

4. Kontribusi digunakan untuk mengetahui sejauh mana pajak daerah dan retribusi daerah memberikan sumbangan dalam penerimaan Pendapatan Asli Daerah. Dalam mengetahui kontribusi dilakukan dengan membandingkan penerimaan pajak daerah dan retribusi daerah periode tertentu dengan penerimaan Pendapatan Asli Daerah periode tertentu pula. Semakin besar hasilnya berarti semakin besar pula peranan pajak daerah dan retribusi daerah terhadap Pendapatan Asli Daerah, begitu pula sebaliknya.

\section{HASIL PENELITAN DAN PEMBAHASAN}

\section{Hasil Penelitian}

Tabel 2 Kontribusi Pajak daerah dan retribusi Terhadap Pendapatan Asli Daerah Kota Manado Tahun Anggaran 2007-2011

\begin{tabular}{|c|c|c|c|c|c|}
\hline \multirow[b]{2}{*}{ Tahun } & \multirow[b]{2}{*}{ PAD } & \multicolumn{2}{|c|}{ Pajak Daerah } & \multicolumn{2}{|c|}{ Retribusi Daerah } \\
\hline & & Jumlah (Rp) & $\begin{array}{c}\text { Kontribusi } \\
(\%)\end{array}$ & Jumlah (Rp) & $\begin{array}{c}\text { Kontribusi } \\
(\%)\end{array}$ \\
\hline 2007 & $54,715,561,525$ & $33,769,067,697$ & 61,71 & $14,809,965,888$ & 27,06 \\
\hline 2008 & $73,468,557,485$ & $39,673,622,883$ & 54,00 & $19,446,859,763$ & 26,46 \\
\hline 2009 & $68,199,913,422$ & $44,486,883,614$ & 65,23 & $16,652,529,750$ & 24,41 \\
\hline 2010 & $92,123,349,135$ & $58,553,045,704$ & 63,55 & $23,789,704,710$ & 25,82 \\
\hline 2011 & $135,204,783,496$ & $99,733,466,374$ & 73,76 & $23,457,737,987$ & 17,34 \\
\hline Total & $423,712,165,063$ & $276,216,086,272$ & 65,18 & $98,156,798,098$ & 23,16 \\
\hline
\end{tabular}

Sumber Data : DISPENDA (diolah) 
Dilihat dari kontribusi pajak daerah terhadap Pendapatan Asli Daerah di tahun 2007 sebesar 61,71\% dari total penerimaan PAD Kota Manado sebesar Rp. 54,715,561,525, pada tahun 2008 memberikan kontribusi sebesar 54\% dari total PAD Rp. 73,468,557,485, tahun 2009 sebesar 65,23\% dari total PAD sebesar Rp. 68,199,913,422, di tahun 2010 kontibusi sebesar 63,55\% dari total PAD sebesar Rp. 92,123,349,135, dan pada tahun 2011 pajak daerah memberikan kontribusi sebesar 73,76\% dari total PAD Rp. 135,204,783,496.

\section{Gambar 1 Penerimaan Terbesar Pajak Daerah Kota Manado}

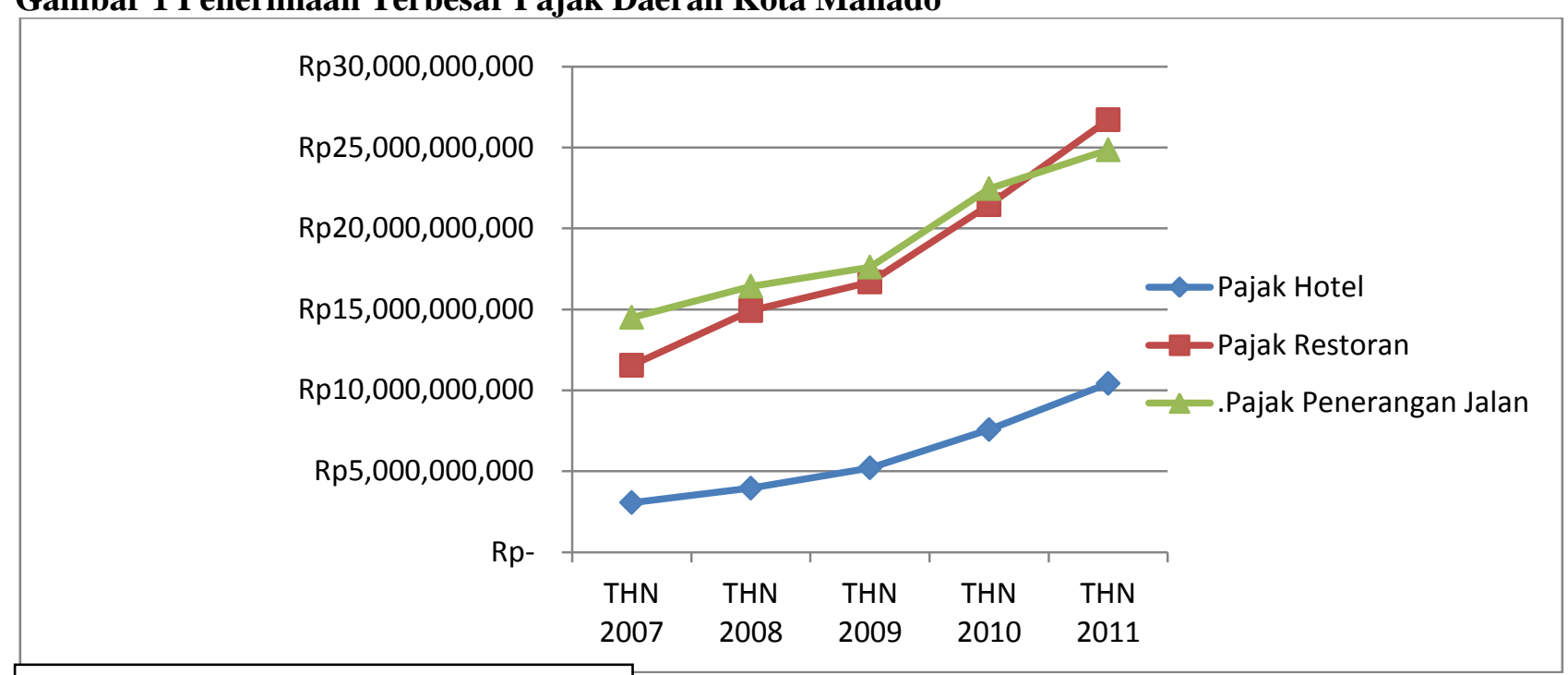

Sumber data : DISPENDA (diolah)

Gambar di atas dapat dilihat bahwa Kota Manado terdapat tiga jenis pajak yang selalu menonjol setiap tahunnya. Pajak tersebut adalah pajak penerangan jalan, pajak restoran dan pajak hotel. Pajak penerangan jalan yang dikelola oleh PT. Perusahaan Listrik Negara (PLN) Kota Manado merupakan pajak yang memberikan kontibusi paling besar dalam stuktur pajak daerah selama jangka waktu 5 tahun. Secara umum, grafik yang ditunjukkan oleh ketiga pajak ini cenderung naik setiap tahunnya. Untuk pajak penerangan jalan, tahun 2007 merupakan titik terendah karena hanya berjumlah Rp. 14.504.397.139. Dalam tahun 2008 terjadi peningkatan sebesar Rp. 1.925.453.390 sehingga menjadi Rp. 16.429.850.529. Pajak penerangan jalan terus meningkat pada tahun 2009, 2010 dan tahun 2011 yaitu sebesar Rp. 17.611.584.335, Rp. 22.463.485.520 dan Rp. 24.855.630.304. Meningkatnya fasilitas jalan yang ada di Kota Manado untuk mencapai visi dan misi Manado Kota Ekowisata menjadi faktor peningkatan kontribusi pajak penerangan jalan sehingga ditahun 2011 merupakan capaian tertinggi dari pajak penerangan jalan. Untuk pajak restoran dan pajak hotel berlaku juga hal yang sama dimana tidak pernah terjadi penurunan jumlah kontribusi yang diberikan oleh kedua jenis pajak tersebut.

Pajak restoran titik terendah terjadi pada tahun 2007 dengan jumlah Rp. 11.542.143.218 dan untuk tahun anggaran berikutnya yaitu tahun 2008, 2009 dan 2010 terus terjadi kenaikan yaitu sebesar Rp. 14.923.639.490, Rp. 16.690.662.230 dan Rp.21.464.517.254. Semakin bertambah banyak dan berkembangnya restoran-restoran di Kota Manado diyakini menjadi faktor peningkatan kontibusi dari pajak restoran sehingga ditahun 2011 merupakan titik tertinggi yang dicapai pajak ini, mampu memberikan masukan dalam struktur pajak daerah sebesar Rp.26.715.829.539. Pajak hotel memberikan kontibusi sebesar Rp.3.062.855.021 pada tahun 2007, dan terus meningkat pada tahun 2008, 2009 dan 2010 yaitu sebesar Rp.3.950.924.990, Rp.5.205.091.655 dan Rp.7.569.391.053. Adanya event-event dan acara besar mengakibatkan banyaknya pengunjung yang datang di Kota Manado sehingga pada tahun 2011 merupakan titik tertinggi dari pajak hotel sebesar Rp.10.424.824.091. 


\section{Gambar 2 Penerimaan Terbesar Retribusi Daerah Kota Manado}

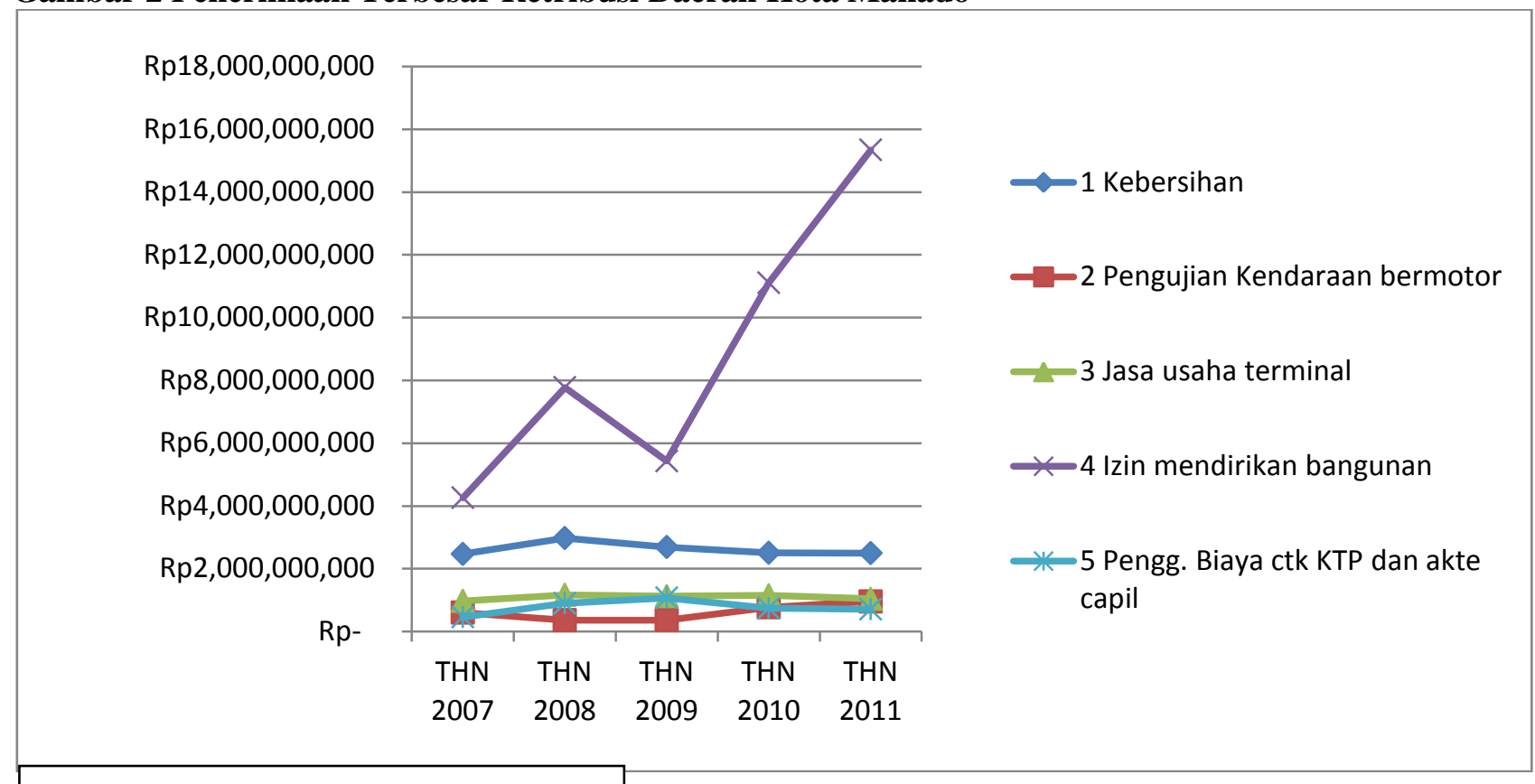

Sumber data : DISPENDA (diolah)

Belum dimilikinya kesadaran masyarakat akan kebersihan Kota Manado mengakibatkan retribusi kebersihan berfluktuatif seperti terlihat pada grafik di atas, pada tahun 2007 sebesar Rp. 2.469.697.250 meningkat tahun 2008 sebesar Rp. 2.977.224.000, kemudian terjadi penurunan tahun 2009 sebesar Rp. 2.690.444.000 dan 2010 sebesar Rp. 2.507.025.000 serta tahun 2011 sebesar Rp 2.496.591.512.

Retribusi pengujian kendaraan bermotor mengalami peningkatan dari tahun 2007 sebesar Rp.602.242.500 sampai 2010 sebesar Rp.772.717.765 dan 2011 Rp.956.763.400 walaupun ada penurunan pada tahun 2008 sebesar Rp.360.770.433 dan 2009 sebesar Rp.365.743.425. Hal ini diakibatkan semakin banyaknya pengguna kendaraan bermotor di Kota Manado.

Gambar di atas menunjukan bahwa retribusi jasa usaha terminal terlihat stabil dikarenakan pengguna jasa usaha ini tidak meningkat atau menurun secara signifikan. Pemasukan retribusi jasa usaha terminal tertinggi terjadi pada tahun 2008 sebesar Rp.1.169.288.000 dan terendah pada tahun 2007 Rp.977.645.100. sedangkan tahun 2011 merupakan penurunan sebesar Rp.1.040.620.000 dari tahun 2009 sebesar Rp. 1.127.071.100 dan 2010 sebesar 1.154.640.000.

Peningkatan yang terjadi pada retribusi izin mendirikan bangunan pada tahun 2007 sebesar Rp. 4.262.845.822 menjadi Rp.11.109.643.270 tahun 2010 dan 2011 sebesar Rp.15.341.502.800, meskipun ada penurunan 2009 sebesar Rp.5.431.020.100 dari Rp.7.774.941.250 tahun 2008. Hal ini disebabkan karena banyaknya pembangunan di Kota Manado.

Penggantian biaya cetak KTP dan akte capil tahun 2007 sebesar Rp.461.918.500 meningkat Rp.897.959.000 dan Rp.1.074.515.000 tahun 2008 dan 2009, kemudian menurun tahun 2007 sebesar Rp.741.149.000 dan Rp.711.540.000 tahun 2011. Peningkatan yang terjadi karena diantaranya peningkatan angka kelahiran dan penduduk yang menikah di Kota Manado.

\section{PENUTUP}

\section{Kesimpulan}

1. Dalam struktur pendapatan asli daerah di Kota Manado, pajak daerah dan retribusi daerah merupakan dua pos penerimaan yang paling dominan, maka jumlah total kontribusi pajak daerah dari tahun 2007 sampai tahun 2011 yaitu sebesar $65,18 \%$ dan jumlah total kontribusi retribusi daerah dari tahun 2007 sampai tahun 2011 adalah sebesar 23,16\%. Terjadinya peningkatan setiap tahun berarti pembiayaan untuk pembangunan daerah akan terpenuhi, hal ini menunjukkan ada kesadaran dari masyarakat untuk membayar pajak.

2. Kondisi yang ditimbulkan akibat dominannya pajak daerah dan retribusi daerah sebenarnya kurang baik, karena dapat menyebabkan ketergantungan keuangan daerah pada kedua pos penerimaan tersebut. Hal ini dapat membuat pos-pos penerimaan yang lain kurang dioptimalkan. 
3. Jumlah penerimaan Pajak daerah dan Retribusi daerah Kota Manado memberikan kontribusi yang baik terhadap PAD sehingga dapat mempengaruhi jumlah PAD yang diterima. Kontribusi terbesar pajak daerah yaitu pada tahun 2011 yaitu 73,76\% dan yang terendah pada tahun 2008 yaitu 54\% sedangkan kontribusi terbesar retribusi daerah terjadi pada tahun 2007 yaitu 27,06\% dan terendah pada tahun 2011 hanya sebesar $17,34 \%$.

\section{Saran}

1. Ketergantungan pembiayaan dalam struktur keuangan daerah pada satu atau dua pos penerimaan dapat menyebabkan terganggunya pendapatan asli daerah jika terjadi gejolak ekonomi. Untuk itu sebaiknya pemerintah daerah lebih menggali, mengupayakan dan mengefektifkan dua pos penerimaan lainnya yaitu pos hasil pengelolaan kekayaan daerah yang dipisahkan dan pos penerimaan lain-lain PAD yang sah.

2. Kontribusi Pajak daerah dan retribusi daerah sudah cukup baik sehingga harus dipertahankan dan akan lebih baik jika lebih ditingkatkan agar kontribusi pajak daerah dan retribusi daerah terhadap PAD semakin besar.

3. Kurangnya jumlah penerimaan retribusi daerah dari tahun anggaran 2007-2011 jika dibandingkan dengan pajak daerah, maka sebaiknya pemerintah daerah Kota Manado lebih mengoptimalkan jasa layanan yang diberikan, baik yang sifatnya komersial maupun yang berbentuk layanan publik.

\section{DAFTAR PUSTAKA}

Agoes, Sukrisno., Trisnawati. 2010. Akuntansi Perpajakan. Edisi 2 Revisi. Salemba Empat. Jakarta. Dinas Pendapatan Daerah Kota Manado. Rencana Strategis Satuan Kerja Perangkat Daerah (2011-2016) Halim. H. 2007. Akuntansi dan Pengendalian Pengelolaan Keuangan Daerah. UPP STIM YKPN. Yogyakarta. Horngren, Charles., Harrison, Walter., Bamber, Linda., 2009 Akuntansi (Accounting). PT Indeks. Jakarta. Ilyas, W., Burton, R. 2011. Hukum Pajak. Salemba Empat.Jakarta.

Kurniawan. Septian Dwi. 2010. Pengaruh Penerimaan Pajak Dan Retribusi Daerah Terhadap Peningkatan Pendapatan Asli Daerah Di Kabupaten Ponorogo. Skripsi. Universitas Islam Negeri Maulana Malik Ibrahim Malang. http//journal.unsil.ac.id. 28 April 2010

Mardiasmo. 2011 ,Perpajakan. Edisi Revisi 2011. Andi. Yogyakarta

Mursyidi. 2009. Akuntasi Pemerintahan di Indonesia. PT Refika Aditama. Bandung.

Siahaan. Marihot. 2010. Pajak Daerah dan Retribusi Daerah. PT. Raja Grafindo Persada, Jakarta

Siregar. Amri. 2009. Analisis Tingkat Efektivitas Pajak dan Retribusi Daerah Sebagai Pendapatan Asli Daerah (PAD) Sumatera Utara. Skripsi. Universitas Sumatera Utara, Medan. http//repository.usu.ac.id/bitstream/123456789/10971/1/10e00047.pdf. 6 Maret 2012

Weygandt, Jerry., Kieso, Donald., Kimmel, Paul., 2007. Accounting Principles Pengantar Akuntansi. Salemba Empat Jakarta

Republik Indonesia 2009, Undang-undang No. 28 tahun 2009, Pajak dan Retribusi Daerah Manado 2004, Undang-undang No. 32. Tahun 2004, Pemerintah Daerah, Manado 